\title{
SOCIO-ECONOMIC IMPACT OF COVID-19 ON FARMERS AND DAILY WAGE EARNERS IN INDIA
}

\author{
R. Hariharan ${ }^{1}$ and S. Raj Mohan ${ }^{2}$ \\ ${ }^{1}$ Assistant Professor, Department of Economics, Alagappa Government Arts College \\ Karaikudi, Tamilnadu. India \\ Email: hariharancrd@gmail.com \\ ${ }^{2}$ Assistant Professor, Department of Geology, Alagappa Government Arts College \\ Karaikudi, Tamilnadu, India
}

\begin{abstract}
The coronavirus, which started in China in December, has been hitting a number of countries in Italy and the United States in recent months and is now spreading rapidly in India. The government of India has been a little more vigilant and has reduced the impact of the text by decree, but the spread of coronavirus is now completely unstoppable. As a result, poor and daily wage earners living in India cannot afford to go out and get food and suffer from the economic burden. Keeping this view, the present study makes an attempt to study the "Socio-Economic Impact of Covid-19 on Farmers and Daily wage Earners in India" is undertaken. So in this microlevel study an attempt is made to assess the socio-economic burden of poor people and daily wage earners from the impact of the Corona virus in India. This study may also bring out some suggestions to reduce the economic burden of poor livelihoods in India.
\end{abstract}

Key words: Coronavirus, Economic Burden, Farmers, Daily Wage Earners India

\section{Introduction}

The coronavirus, which began spreading in China, last December, has spread to all continents except Antarctica today. More than one million people worldwide die from this virus. Countrywide curfews have been in effect since the $25^{\text {th }}$ March 2020 in India. This curfew is essential if the coronavirus is to spread. The curfew has reduced the number of people walking outside. Stores are closed and service departments are only partially operational. Production has come to a complete standstill, as all enterprises have closed down. The agriculture sector is now only partially functioning. The spread of this deadly disease will have serious consequences for our economy. In this life-saving war, we have to confront these economic impacts unprecedentedly. For that reason, this article addresses how poor people, farmers and daily wage earners are affected.

\section{Sign and Symptoms of Coronavirus}

The Coronavirus that enter your body's cells first invades and controls them. Coronavirus, officially referred to as SARS-COV-2 is a virus that enters the body through respiration or when a virus spreads, touching the face and then touching the face. It first infects cells in the vicinity of the throat. They go to the respiratory tract and lungs and turn them into "coronavirus manufacturing plants". It creates large numbers of new viruses and injects them into the body, causing more cells to become infected. Those who affected won't get sick at an early stage. Some people will never show symptoms. The duration of the disease, i.e. the onset of infection and the onset of symptoms, varies from person to person. But on average it is five days. Almost everyone will be like this. Eight out of 10 people infected with the coronavirus virus will be mildly infected with Covid-19. The main symptoms are fever and cough. Body aches, sore throats, and headaches. But these are not supposed to come. Fever and discomfort can be caused by the function of your immune system 
against infection. This virus can be infectious. Other cells of the body will recognize that something is wrong and produce a chemical called cytokines. These are the ones that act as immunity. But it can also cause physical pain and fever. Coronavirus cough is usually dry and coughing after the virus becomes infected, causing irritation in the cells. Some people have bad mucus during coughing - it is the mucus from the lungs killed by the virus. It is treated by bed rest, drinking plenty of drinks and paracetamol. No special treatment of the hospital is required. This condition lasts for about a week - this is where most people will heal. This happens because the immune system fights the virus (Hindu Tamil, 2020).

\section{Setting the Problem}

The coronavirus, which started in China in December, has been hitting a number of countries in Italy and the United States in recent months and is now spreading rapidly in India. The Government of India has been a little more vigilant and has reduced the impact of the text by decree, but the spread of coronavirus is now completely unstoppable. As a result, poor and daily wage earners living in India cannot afford to go out and get food and suffer from the economic burden. This article seeks to explain how poor Indian people and daily wage earners are suffering from a lack of food and money on hand. This article also seeks to explain what measures our Indian Government is taking to alleviate their poverty condition in the present context.

\section{Objectives}

The following are the objectives of this paper: (1) To understand the Incidence and number of cases affected by Corona diseases in India during the lockdown period; (2) To study the impact of Coronavirus in the lockdown period in India; (3) To assess the socio-economic burden of poor people and daily wage earner from the impact of Coronavirus in India and (4) to suggest some suitable policy measures to reduce the economic burden of poor livelihoods in India in the curfew period.

\section{Data and Method}

The paper uses the secondary sources of First 21 days Lockdown Period only from report of the Ministry of Health and Family Welfare, Government of India, Health and Family Welfare Department in Tamilnadu, Daily News Papers in Tamil and English Language and other research studies from the internet sources and carries out the analysis to realize its objectives.

\section{Impact of 21 days Lockdown in India}

The 21-day curfew has been implemented nationwide since the $25^{\text {th }}$ of last month to curb corona. What happens when curfews continue to be announced? Has any impact of the Corona last 21 days of curfew in India? The question arises. Statistics from different sources suggest that the corona's vulnerability is low. Shamika Ravi (2020) of Brookings said: - Corona's vulnerability is slowing. Active vulnerabilities double every 7 days. India Corona (Covid-19) has reported that 4778 cases were reported in India on April 6. The number of casualties doubled to 10,455 on April 13, which means active cases are now doubling every 7 days. Prior to this, cases had doubled every four days. In India, 2059 cases were reported on April 1, with the number doubled by April 5 to 4289. The number of impacts may be rising daily, and growth rates have slowed since April 6. In terms of deaths, 361 deaths have doubled every five days (from April 8 (184 deaths) to April 13), doubled every four days (March 31 (49 deaths) to April 4, (99 deaths). Analysis of the Institute of Mathematical Sciences in Chennai shows that the rate of infections has also declined. The reproductive value, also known as $\mathrm{R}$ Nat or $\mathrm{R} 0$, has decreased to 1.55 from 6 April to 11 April with the average number of people infected with the virus. The coronavirus infected 1.55 people after the curfew, which infected 1.83 people before the curfew. 


\section{Social Impact}

In the context of curfew, which is the cause of coronavirus, the social problems that people face are very difficult for parents who are married to their children six months ahead of time. Moreover, those who rely solely on work in the outdoors are unable to see the bodies of their parents, who have died as a result of old age. Due to the closure of small hospitals and clinics located in villages and small streets, it is very difficult for parents who have children to seek first aid medical care for their small children. The public is at home in the curfew. Accordingly, the husband and wife are at home all day watching each other, causing unwanted fights and quarrels within them. As a result, domestic violence against women at home is reportedly on the rise. Studies have shown that children are also more vulnerable to mental retardation as parents are unable to take their children to the park and outdoors as a reason for the curfew. These are main social issues in the impact of Coronavirus in India.

\section{Economic Impact}

In the context of curfews as a cause of coronavirus, this section will show how much other countries have allocated for the prevention of coronavirus and how much India has allocated for the prevention of coronavirus. The section also seeks to explain how farmers, daily wage-earners and grassroots workers struggle with their food and economic needs and are unable to participate in social and social activities in the curfews period.

\section{Macro-Level Approach}

The next word that threatens all the nations of the world is the corona. India is no exception. But in the face of a catastrophe, the generous financial allocation can be the right way for people to be prepared in advance. All countries have realized this. That is why they have announced that they will face Corona at 10-20 percent of its GDP. The US government has announced two trillion talons as a relief. This is about 10 percent of the country's GDP. Britain and Germany have announced a 20 percent reduction in their GDP. France, Spain and Japan have pledged to provide 10-15 percent relief. Similarly, our Government of India has announced an allocation of Rs 1.75 lakh crore. Overall, it is just 0.8 percent of India's GDP. If the existing deduction for social welfare is already in place, the new allocation will be around Rs one lakh crore. That is only 0.5 percent of GDP. This is a very small amount compared to other countries. Increasing the allocation of funds is important as the Government of India continues the curfew. Mental health is our greatest strength. Not only is that, but the sustainability of the economy is also one of the major responsibilities of the present Government of India.

World Bank (2020) estimates The Indian economy is expected to lose over 32,000 crores every day during the first 21-days of lockdown which was declared following the coronavirus outbreak. Up to 53 percent of businesses in the country will be affected. Supply chains have been put under stress with the lockdown restrictions in place; initially, there was a lack of clarity in streamlining what is an "essential" and what isn't. Those in the informal sectors and daily wage groups are the most at risk. A large number of farmers around the country who grow perishables are also facing uncertainty. Various businesses such as hotels and airlines are cutting salaries and lying off employees. The live events industry has seen an estimated loss of 3,000 crores. Business Today (2019) report said that the four Indian states with highest confirmed COVID-19 cases including deaths are Maharashtra, Delhi, Tamilnadu and Uttar Pradesh. These states are already constrained with finances. Maharashtra government has announced paying salaries to the government staff in two instalments. Both southern states Kerala and Tamil Nadu have asked Centre for financial grants to fight the Covid-19 battle as cases are on the rise every day. Clearly, the domino effect of Covid-19 and slowdown in the economy will push the states in more debt. 


\section{Micro-Level Approach}

With the curfew being enforced across India, the economic conditions of the poor people who live here are questionable. If you take the farmer now, the chances of selling the rice paddy in several states of South India are not satisfactory. In the present situation, in many districts of Tamil Nadu, government procurement centers have to buy paddy from the farmers without having to buy the paddy in their hands. If an emergency is to be sold to a private person, it has to be sold at a lower price than the government has set. Moreover, in the northwestern states of India, the harvest of wheat and pulses has been severely affected due to inadequate agricultural labor. Workers are unable to bring workers from the neighboring districts for the curfew. Farmers who produce and sales of food grains and vegetables have been struggling with the curfew. The flower and banana cultivators have also suffered. Because the temples are closed and the wedding ceremony is not ubiquitous, the need for flowers is gone. The ban on the sale of banana leaves has completely stalled due to the closure of restaurants. Therefore, such farmers lose their income and become debtors. Two-thirds of farmers in India depend on livestock for their immediate income. But with the closure of restaurants and tea shops, the need for milk has drastically reduced. The closure of tea shops has led to a 30percent decrease in milk sales, according to press reports. Poultry farming has also significantly benefited farmers. Rumors have spread of chickens spread by chickens, and farmers and workers who rely on it are now suffering. Farmers who rely on poultry and livestock will not be given adequate relief to their livelihoods in the future.

On the one hand, farmers are suffering from this as curfew has been implicated as the cause of the corona epidemic, but on the other hand, non-agricultural workers and their livelihoods have become increasingly questionable. The income of the poorest people living in urban areas and they are working in urban shops is also in questionable, as all the shops are currently closed as a corona attack. They are unaware of the way to eat and are unable to go to work because of a restraining order. And even those who own non-food stalls and manage the economic burden are now stranded at home without any income. The Coronavirus has had such a drastic economic impact in India especially poor people in the country.

\section{Conclusion}

Curfew has been implemented in various countries to control coronavirus. However, the immediate withdrawal of the curfew is dangerous. The curfew should be gradually withdrawn. India is on the right track. After curfew, people must follow the social gap. Then only the virus spread can control. Victims of coronavirus infection must be monitored digitally. Then only the coronavirus can be prevented from infecting others. The government must come forward to produce the virus identifying instrument at the country level. Then only it can be possible to produce more tools and can detect more patients more quickly. Social problems can be alleviated to some extent by allowing people to attend weddings with the precaution and safety of smallholdings and by allowing people to travel to their hometowns by state vehicles from their parents and or their relations death. Family problems can be alleviated to some extent by counseling the women through the women's courts and avoid family problems by engaging themselves in exercise and yoga.

Farmers can reduce their economic burden by allowing the government to procure the products they have produced and to allow the small businessmen to do business within the place in the absence of reprimand. Daily wage earners and Poor people have migrated and stayed there. The State Government should help them to get the food and clothing they need. The government should take some measures by the way of cash in hand or any mode of help to ensure that small businesses are not harmed. If they extend curfew, the government should pay the cash in hand at a reasonable amount to the families who below the poverty line. The government should provide 
more incentives for health workers, police personnel and local workers who have been working tirelessly in the eradication of Coronavirus.

\section{References}

1. https://static.hindutamil.in/hindu/icici/TAMILTHCHENNAI_2020-04-18.pdf

2. https://static.hindutamil.in/hindu/icici/TAMILTHCHENNAI_2020-04-17.pdf

3. https://static.hindutamil.in/hindu/icici/TAMILTHCHENNAI_2020-04-15.pdf

4. https://static.hindutamil.in/hindu/icici/TAMILTHCHENNAI_2020-04-14.pdf

5. https://static.hindutamil.in/hindu/icici/TAMILTHCHENNAI_2020-04-13.pdf

6. https://www.businesstoday.in/current/economy-politics/covid-19-impact-maharashtra-keralatamil-nadu-up-stare-at-big-fiscal-hole/story/400084.html

7. https://economictimes.indiatimes.com/news/politics-and-nation/coronavirus-faced-with-anunprecedented-challenge-how-is-india-faring/articleshow $/ 74986805 . \mathrm{cms}$ ?from $=\mathrm{mdr}$

8. https://www.kalaignarseithigal.com/tamilnadu/2020/04/08/a-brief-about-dmk-mp-tr-baalurequest-for-covid-19-prevention-on-all-party-meeting

9. https://webcache.googleusercontent.com/search?q=cache:Q7S18eyhhpgJ:https://www.mohf w.gov.in/

10. World Bank sees FY21 India growth at 1.5-2.8percent, slowest since economic reforms 30 years ago". The Hindu. PTI. 12 April 2020. ISSN 0971-751X. Retrieved 13 April 2020 